Marie-Luisa Frick and Andreas Oberprantacher:

\title{
Shared is not yet Sharing, Or: What Makes Social Networking Services Public?
}

\begin{abstract}
:
According to a libidinally charged slogan, Social Networking Services are meant to give "people the power to share and make the world more open and connected." But does the digital act of sharing personal information - invested in so many of the New Social Media - make such internet domains a public realm? What characterizes actually the public according to classical political theory, and what sort of performances become visible in digital fora under the banners of interactivity, friendship and an alleged dissolution of boundaries? Against the background of increasingly elastic borders between things considered private and spaces declared public as well as of a remarkable spectrum of modes of sharing - ranging from disclosing daily trivia to collectively expressing political dissent - our contribution will examine the ambivalence of sharing in Social Networking Services, not least in Facebook, in terms of a paradoxical nexus of passions and risks.
\end{abstract}

\section{Agenda:}

Generation F 18

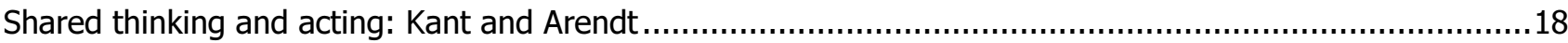

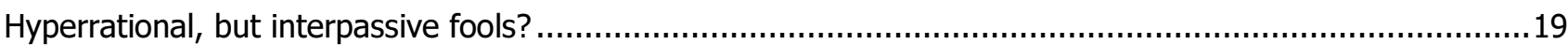

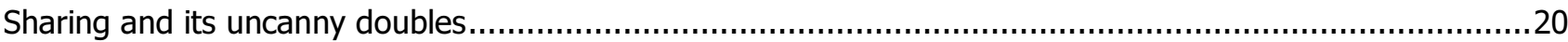

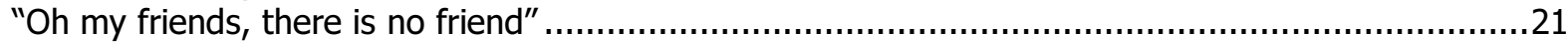

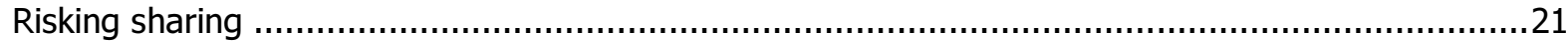

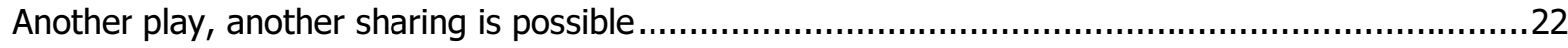

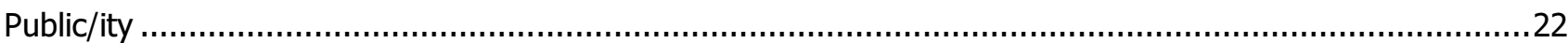

\section{Authors:}

Ass.-Prof. Dr. Marie-Luisa Frick:

- Department of Philosophy, University of Innsbruck, Innrain 52d, 6020 Innsbruck, Austria

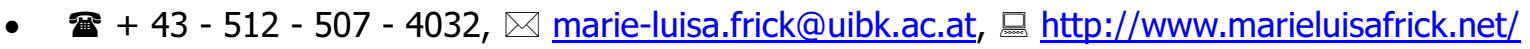

- Relevant publications:

- Moralischer Relativismus. Antworten und Aporien relativistischen Denkens in Hinblick auf die weltanschauliche Heterogenität einer globalisierten Welt. Wien/Münster, Lit 2010, 311 p.

Ass.-Prof. Dr. Andreas Oberprantacher:

- Department of Philosophy, University of Innsbruck, Innrain 52d, 6020 Innsbruck, Austria

- ? 0 + 43 - 512 - 507 - 4029, $\square$ andreas.oberprantacher@uibk.ac.at

- Relevant publications:

- "Beyond Rivalry? Rethinking Community in View of Apocalyptical Violence". Contagion: Journal of Violence, Mimesis and Culture 17.1 (2010). 175-187.

- "Culture Jammed: The Art of Subverting Violence". Medienimpulse. Beiträge zur Medienpädagogik 2 (2011). <http://www.medienimpulse.at/articles/view/310>.

- "Off Limits. Elastic Border Regimes and the (Visual) Politics of Making Things Public". Hug Theo and Sützl, Wolfgang (eds): Activist Media and Biopolitics. Innsbruck: iup. Forthcoming. 


\section{Generation F}

Is Facebook perhaps that dispositif by which hundreds of millions of users are slowly but steadily turned into digital zombies whose frightening jouissance consists in nothing but sharing statuses with a spectral audience accepted as "friends"?

At least for those cultural and political theorists that have flipped the janiform coin named New Social Media as to only display its dystopic downside, it must have come as a surprise that the Facebook generation is also capable of generating revolutionary sentiments - for which the recent Arab Spring provides ample evidence. ${ }^{1}$ Considering the latest political developments in a range of autocratic regimes it is in any case emblematic that the Egyptian internet activist and Google executive Wael Ghonim, who has been called "spokesman for a revolution ${ }^{\prime 2}$ by Mohamed Elbaradei and who is heading the list of the 2011 TIME 100 most influential people in the world, enthusiastically thanked Mark Zuckerberg for having made Facebook such a collaborative environment that served as an accelerant in Egypt's political revolution:

"I want to meet Mark Zuckerberg one day and thank him. [...] This revolution started online. This revolution started on Facebook. This revolution started [...] in June 2010 when hundreds of thousands of Egyptians started collaborating content. We would post a video on Facebook that would be shared by 60,000 people on their walls within a few hours. I've always said that if you want to liberate a society just give them the Internet. ${ }^{10}$

Notwithstanding Ghonims jubilatory testimonial, the protuberant narrative of a "Facebook Revolution" is not free of guile. Even if it is the case that against

1 The question to what extent Social Networking Services fostered the revolutions in Tunisia and Egypt or support the uprisings in other countries in the region is highly controversial. However, empirical data supports the assumption that Facebook does indeed matter since the number of users in the Arab world increased by 30 percent in the first quarter of 2011. Within this timeframe, Egypt, for example, has gained 2 million new users. Still, Egypt is outnumbered by 5.11 percent of the Tunisian population who have joined the service between January and April 2011. (Dubai School of Government: Arab Social Media Report. 1.2 (2011). <http://www.dsg.ae/portals/0/ASMR2.pdf >).

2 Elbaradei, Mohamed: "Wael Ghonim: Spokesman for a Revolution". TIME.

3 "Ghonim: Facebook to Thank for Freedom". CNN. the assumption that "people have really gotten comfortable not only sharing more information and different kinds, but more openly and with more people", Zuckerberg does understand Facebooks first and foremost role "to constantly be innovating and be updating what our system is to reflect what the social norms are ${ }^{A}$, one needs to be critically aware that such an alleged role of 'reflecting' a globalized society's changing social norms corresponds as much to a re-definition of social spaces and practices out of particular, sometimes hegemonic interests as it may also regenerate what Hannah Arendt identified as the pulsating heart of truly democratic politics: the public realm. In this ethical twilight of a networked sociality, for which profiling and posting have become mandatory performances, our discussion of different modes of sharing shall commence by first of all drawing on a genealogy of the very idea of the public as outlined in the works of Immanuel Kant and Hannah Arendt. In a second step we shall discuss two contemporary critiques of the digital culture of sharing, namely those by Eva Illouz and Slavoj Žižek. Eventually, the ambivalence of sharing oneself in Digital Networking Services shall be exposed by highlighting three problematic dimensions that allow us to critically reflect on a crucial distinction: that of public and publicity.

\section{Shared thinking and acting: Kant and Arendt}

To understand which sort of public may arise out of the new digital fora and to evaluate its potential quality, it is pertinent to highlight those concepts that have strongly been linked, as far as two of the most prominent representatives of political ethics are concerned, to the idea of shared thoughts and shared action.

For Kant the public realm is the core condition for universal enlightenment, defined as the overcoming of one's self-inflicted immaturity. Apart from that, the use of one's reason is inextricably coupled with, if not dependent on, open exchange and discourse with others. ${ }^{5}$ What Kant is emphasizing in particular is that the freedom of thought is inherently connected to the freedom of speech and to that of the

\footnotetext{
4 Mark Zuckerberg in an interview with Michael Arrington on the occasion of the 2010 The Crunchies Awards. $<$ http://www.ustream.tv/recorded/3848950>.

5 cf. Kant, Immanuel: Was heißt: Sich im Denken orientieren?
} 
press. ${ }^{6}$ He asks: to what extent and how accurate would we really be able to think if we were not allowed to reason in concert with others who are sharing their thoughts with us, while we are sharing ours with them? In this respect, any effort to restrict one's freedom to share thoughts with others will inevitably imply a violation of the freedom of thought in general. According to Kant, the public realm needs to remain accessible for everybody who is willing to freely exercise one's reason. ${ }^{7}$ When it comes to the freedom of speech, however, this Kantian generosity is backed up with a principal distinction of the private and the public that is not without ambivalences. Whereas Kant calls for an unrestricted public use of one's reason, the private use of it - in terms of a professional that is bound by particular work duties - can be restricted without running contrary to the very end of universal enlightenment: ${ }^{8}$ in my role as intellectual I have unlimited access to the public discourse and may freely exercise my reason; as a professional subjected to the responsibilities and limitations of my vocation Kant mentions army officers and priests - my factual freedom of contributing to a society's open discourse and of criticizing is finite.

Hannah Arendt agrees with Kant in as much as she, too, defines the public as an actualization of a particular mode of sharing. In her conception, however, the public is constituted to a lesser extent by the thoughts that can be shared; rather, it is one's self that is at stake. For Arendt, the substantive relation between the public realm and the selfdisclosure of its subjects gains its particular significance from what she refers to as acting. It is through acting and speaking that we get involved and finally make our appearance in the human world, as Arendt puts it:" "With word and deed we insert ourselves into the human world, and this insertion is like a second birth [... $]^{\prime 10}$. Public speech and action reveal a person's unique distinctness which in Arendt's philosophy is an integral moment of the human condition, very much like the plurality of our experiences and points of view. According to Arendt, when people are publicly acting and speaking, they are also (unintentionally) answering the question "Who are you?":

\footnotetext{
${ }^{6}$ Kant, Immanuel: Was heißt: Sich im Denken orientieren? 144

${ }^{7}$ Kant, Immanuel: Was ist Aufklärung? 36

${ }^{8}$ Kant, Immanuel: Was ist Aufklärung? $36 f$.

${ }^{9}$ Arendt, Hannah: The Human Condition. 179

${ }^{10}$ Arendt, Hannah: The Human Condition. 176
}

"This disclosure of 'who' in contradistinction to 'what' somebody is - his qualities, gifts, talents, and shortcomings, which he may display or hide - is implicit in everything somebody says and does".11

Not least in view of the basically pluralistic human condition such public revelations are potentially risky: On the one hand, one is running the risk of being rejected by others; on the other hand, one might also be surprised by discovering one's veritable self. ${ }^{12}$

Another function of the public that is stressed by Arendt is its capacity to gather people in such a way that it relates them as much as it keeps them apart, a particular capacity that eventually "prevents our falling over each other ${ }^{13}$. In this sense, the public needs to be distinguished from radical privacy, which refers to a condition where no one is able to "see" and "hear" or to be "seen" and "heard". Ultimately, Arendt argues that the public realm constitutes the very condition for a shared world: the existence of others that see what we are seeing and that hear what we are hearing ensures the reality of this world as well as the reality of ourselves.

\section{Hyperrational, but interpassive fools?}

Considering some of the more important technological changes in the past few decades, we may well assume that the reality of this world has changed dramatically along with the reality of ourselves: Ever since the ARPANET's establishment of the highly flexible method of "packet switching" as the technology used for setting up highly integrated computer networks, the strategy of a multidirectional transmission of messages has constantly gained in significance. But more than just being a technical achievement in the field of ICT, sharing data, information, but also oneself has eventually become a mode of living that defines and encompasses devices as various as File Sharing, Online Dating, Social Networking Services etc. Not least in view of these recent phenomena that mark a comprehensive transformation of social spaces and practices, the

\footnotetext{
${ }^{11}$ Arendt, Hannah: The Human Condition. 179

${ }^{12}$ Arendt, Hannah: The Human Condition. 179f.

${ }^{13}$ Arendt, Hannah: The Human Condition. 52
} 
sociologist Illouz contends in her book Cold Intimacies that

"the act of posting a profile allows the Internet [...] to convert the private self into a public performance. More exactly, the Internet makes the private self visible and publicly displayed to an abstract and anonymous audience, which, however, is not a public (in the Habermasian sense of that word ${ }^{14}$ ) but rather an aggregation of private selves. On the Internet, the private psychological self becomes a public performance. ${ }^{\prime \prime 5}$

Illouz' analysis confirms Zuckerberg's expectation according to which the digital passion for sharing (not just information but, most importantly, oneself) will overcome the modern dichotomy of public and private spheres by facilitating performances that are hybrid - with one notable difference though: According to Illouz, we should consider the genuine risk that this new cultural constellation might eventually turn us into "hyperrational fools", i.e. into "somebody whose capacity to judge, to act and ultimately to choose is damaged by a cost-benefit analysis, a rational weighing of options that spins out of control." ${ }^{16}$ Put otherwise: the more the Social Networking Services are used to digitally enhance and spread out the users' psychological landscapes by consequently minimizing the jeopardy of being "ridiculed" by others - the absence of a "dislike"button in Facebook is all but circumstantial evidence in this respect - the less space is left for forms of sharing that may cross particular allotments and create new commonality.

Along similar lines, Žižek has also recently argued that the pervasive notion of interactivity, which is widely applied to characterize mankind's liberation from a consumerist mentality by simultaneously redefining man-machine relationships, is paralleled by its "shadowy and much more uncanny supplement/double, the notion of 'interpassivity'. "177 According to Žižek, the more the contemporary concept of activity is defined by the desire and as the capacity to defer one's passivity to a personalized device, the more opportunities of (passively) enjoying will also have to be delegated. In precisely this

14 For Jürgen Habermas the public sphere does not only depend on the quantity of participation, but also on the quality of discourse. Cf. Habermas, Jürgen: Strukturwandel der Öffentlichkeit. (Note by authors)

${ }^{15}$ Illouz, Eva: Cold Intimacies. 78

${ }^{16}$ Illouz, Eva: Cold Intimacies. 113

17 Žižek, Slavoj: The Plague of Fantasies. 111 sense, the interactive user is plagued by a relentless activism whose main purpose is that of effectively preventing inter-change while keeping up appearances, and this may indeed be termed "false activi$\mathrm{ty}^{\prime \prime 18}$.

And what better device to illustrate this paradoxical inversion of acts of sharing than Facebook itself, which allows its users with almost no effort at all i.e. with one single click - to join political causes worldwide without having to renounce the comfort of a lounge chair? In fact, as Sara Louise Muhr and Michael Pedersen have pointed out in their "application" of Žižek's notion of interpassivity to the domain of Facebook, there is a chance that Social Networking Services are effectively depoliticizing the internet:

"You may think you enjoyed the intimate time with your friends or that you changed something (and you may indeed have changed something) by joining yet another Safe Darfur group - but in fact Facebook did it for you. [...] I can continue to have a full commitment to a political action, as long as I don't have to make choices about what to actually do, and how to fit it into my already too-crowded life. ${ }^{\text {,d9 }}$

By blending Illouz' and Žižek's critical interventions and by recalling Kant's and Arendt's conception of the public, we shall now attempt to draw an ethical dividing line that distances the public from publicity and along which different modes of sharing can be discerned. Such a dividing line is itself not without ethical controversy, but it may nevertheless be of critical use value for transforming the rather naïve and sometimes problematic attitudes towards Social Networking Services and for supporting a different form of commonality.

\section{Sharing and its uncanny doubles}

Against the background of our preliminary historical genealogy of spaces, ideas and practices shared as and in public, and the subsequent discussion of a digital environment in which it is no longer clear what is private and what is public, what is active and what is passive, the following three dimensions are of particular importance for a political ethics of sharing.

\footnotetext{
18 Žižek, Slavoj: The Plague of Fantasies. 115

19 Muhr, Sara Louise and Pedersen, Michael: "Faking It on Facebook". 275
} 


\section{"Oh my friends, there is no friend"}

If it is true that Facebook is the current, highly emotionalized meridian of all Social Networking Services, one may conclude that for such New Social Media it all comes down, as the largest company's mission statement suggests, to "connect and share with the people in your life ${ }^{20}$, i.e. with those we consider to be our friends. As simple and appealing as this invitation to participate in a globalized village consisting of aggregated, friendly profiles may sound, it is of critical importance to acknowledge that it silently defines friendship as that magic social operator which henceforth shall regulate most issues of belonging. Especially in view of the Social Networking Services' genuine potentiality to displace some of the territorial markers, which so far have delimited people's communication according to fragmented and segmented nationalized spaces, we are indeed confronted with new forms of transversal bonding. Not incidentally, Arendt showed a great interest in exploring the meaning of civic friendship when discussing how public life has eventually emerged in the Greek poleis:

"In discourse the political importance of friendship, and humanness peculiar to it, were made manifest. This converse (in contrast to the intimate talk in which the individuals speak about themselves) [...] is concerned with the common world, which remains 'inhuman' in a very literal sense unless it is constantly talked about by human beings. For the world is not humane just because it is made by human beings, and it does not become humane just because the human voice sounds in it, but only when it has become the object of discourse. ${ }^{121}$

No doubt there is a lot of 'talk' adorning the 'walls' of those who are displaying a digital profile in Facebook. But as Arendt has repeatedly emphasized, public discourse does not equal intimate talk. Bearing this fine distinction in mind, the public quality of sharing in Social Networking Services will then depend on the "unfriendly" disposition to break the chains of intimacy and to engage in debates. If Facebook and its users are serious about "giving people the power to share and make the world more open and connected ${ }^{\prime 2}$, it is time for shifting the

$20<$ http://www.facebook.com/>

${ }^{21}$ Arendt, Hannah: "On Humanity in Dark Times: Thoughts about Lessing". 24

${ }^{22}$ About: <http://www.facebook.com/facebook> attention from what is posted on individual's profiles to what is discursively shared (in groups).

Such a shift would first of all require that users develop a critical awareness regarding the allurements of self-presentations in terms of simply playing to the gallery. Especially when considering the increased readiness to use Social Networking Services for political agitation in the broadest sense, the question needs to be addressed if such singleclick outreach efforts are really directed at supporting a particular cause (if they are "shots into the moral darkness" ${ }^{\prime 23}$, so to say), or if they are rather intended to fabricate an image of the self in order to anchor it in the minds of those potentially auditing? If the latter applied, there would indeed be no genuine difference between participating in a dedicated group of political activists and "choosing [...] an outfit to wear ${ }^{\prime 22}$.

\section{Risking sharing}

The public envisioned by Kant as a realm constituted by freely shared thoughts and formed by an unimpeded exercise of one's reason is no longer a mere utopian postulation, nevertheless it remains an imperfect privilege of - at best: partially - "open" democratic societies. When turning to Arendt's understanding of the public realm as that site where speech and action are shared to the extent that one's self is ultimately disclosed to others, one cannot but notice, however, that the risks implied by such an existential self-revelation are spread disproportionately: there is, in short, a crucial difference between an Italian citizen, for example, who opposes the use of nuclear energy by joining a protesters' group on Facebook on the one hand, and, perhaps, an Iranian student openly supporting an imprisoned opposition leader on the other. Considering Arendt's argument that an anonymous sharing of information and action cannot possibly generate a public (democratic) realm - e.g. when she stresses that "[w]ithout the disclosure of the agent in the act, action loses its specific character and becomes one form of achievement among others ${ }^{25}$ - the following question arises: what if political actions are directed against a totalitarian regime and if anonymity is crucial to uphold the integrity of the actors involved? If emerging and thus exposing one's inimitability - discussed by Arendt as man's second

\footnotetext{
23 Vallor, Shannon: "Flourishing on Facebook"

24 Meikle, Graham: "It's Like Talking to a Wall". 17

${ }^{25}$ Arendt, Hannah: The Human Condition. 180
} 
birth - ultimately results in risking one's very intimate death? Would it make sense to argue that such acting is lacking the quintessential public quality and, as a result, it is not political in Arendt's own terms? But as she also notes, only somebody willing to continue to exist within a given community or commonwealth and to maintain relations with others therein will finally be ready to take the risk of emerging - in public. Hence, one could argue that acting publicly in a political sense is per definitionem a specificity of an at least potentially "open" society, i.e. political acting itself requires social conditions where risks are not very likely lethal. One could even argue in continuation of Arendt's concession that the duty to keep promises may be suspended when extraordinary circumstances apply ${ }^{26}$ - including such when the state fails to fulfill its basic responsibilities -, that anonymous political acting within Social Networking Services is a legitimate political strategy as long as the agenda is that of enabling conditions under which masking is no longer necessary. In view of this modified Arendtian argument one could contend that whereas a democratic commonwealth should be alarmed by the rise of anonymity, in the case of repressive regimes concealed and undeclared acts of sharing are the only feasible option for manifesting dissent.

\section{Another play, another sharing is possible}

If the financial speculation over Facebooks stock market valuation, peaking at 50 billion USD at the beginning of 2011, tells us anything of significance for a political ethics of sharing, it concerns the webservice's legal status as a private company that is owned and controlled by a restricted group of entrepreneurs, and headed by a single individual. This is remarkable insofar as it evidences a performative contradiction: the very institution which has defined connecting and sharing its unique selling proposition is itself a profit-oriented enterprise that is neither reflecting the idea of the commons, nor is it up to public scrutiny. ${ }^{27}$ In this sense, Facebook can be understood as a digital space

\footnotetext{
${ }^{26}$ Arendt, Hannah: Zur Zeit. 151

${ }^{27}$ In analogy to Derrida's main argument put forward in his paper "Structure, Sign and Play in the Discourse of the Human Sciences", one could claim with regard to Facebook that it is an almost too perfect exemplification of the ambivalence of a center which on the one hand "permits the play of its elements inside the total form", i.e. the connecting and sharing of user profiles, while on the other hand it "also closes off the play which it opens up and makes possible." Derrida, Jacques: "Structure, Sign and Play in the Discourse of the Human Sciences". 352
}

where everything can be shared, just not Facebook itself. But wouldn't it be consequential to share also what until now constituted the Social Networking Service's secretive centre? Wouldn't it be more coherent - also in the light of Facebooks notoriously slack handling of user privacy - to turn to an open source alternative? How about a decentralized network like Diaspora ${ }^{28}$ ?

\section{Public/ity}

As much as sharing in its predominant mode of posting on one's profile has become the undisputed fetish of a whole New Social Media industry, this lifestyle raises a great many ethical concerns ranging from the risks of an uncommitted, yet openly staged affectivity or closed environments declared as 'collaborative' to the ambivalences of sharing in terms of a promising, active participatory process vs. interpassive, disjointed acts of having trivia shared.

As recent uses of Social Networking Services are demonstrating, not least in view of the Arab youths' impressively coordinated uprisings against the whims of their rulers, it would be a grave mistake to assume that devices have a predefined operating range. Even Facebook can become an activist media in the hands of people who share the revolutionary passion to establish public life. Against an all too enthusiastic and libidinally charged rhetoric of interconnectivity, however, it is expedient to retain a sober, critical distance to the technology at our hands and to furthermore concede to ourselves some undivided passivity. Perhaps this will help us to form an unprecedented commonality that actualizes de-centered and yet engaged modes of sharing without at the same time confounding the public with publicity and discourse with chatter.

\section{References}

"Ghonim: Facebook to Thank for Freedom". CNN. <http://edition.cnn.com/video/\#/video/bestoftv/ 2011/02/11/exp.ghonim.facebook.thanks.cnn>.

Arendt, Hannah: The Human Condition. Chicago, University of Chicago Press 1958.

Arendt, Hannah: "On Humanity in Dark Times: Thoughts about Lessing". Men in Dark Times. New York, Harcourt, Brace and World, 1968. 331.

\footnotetext{
${ }^{28}<$ https://joindiaspora.com/>
} 
Arendt, Hannah: Zur Zeit. Politische Essays. Hamburg, Rotbuch-Verlag 1999.

Derrida, Jacques: "Structure, Sign and Play in the Discourse of the Human Sciences". Writing and Difference. London, Routledge 2001. 351-370.

Dubai School of Government: Arab Social Media Report. 1.2 (2011). <http://www.dsg.ae/portals/O/ASMR2.pdf>.

Elbaradei, Mohamed: "Wael Ghonim: Spokesman for a Revolution". TIME. <http://www.time.com/time/specials/packages/ article/0,28804,2066367 2066369 2066437,00.htm $1>$.

Habermas, Jürgen: Strukturwandel der Öffentlichkeit. Untersuchungen zu einer Kategorie der bürgerlichen Gesellschaft. Mit einem Vorwort zur Neuauflage 1990. Frankfurt am Main, Suhrkamp 2009.

Illouz, Eva: Cold Intimacies: The Making of Emotional Capitalism. Malden, Polity Press 2007.
Kant, Immanuel: "Beantwortung der Frage: Was ist Aufklärung?" Akademie-Ausgabe VIII. Berlin: de Gruyter 1784/1968a. 33-42.

Kant, Immanuel: "Was heißt: Sich im Denken orientieren?" Akademie-Ausgabe VIII. Berlin: de Gruyter 1784/1968b. 131-148.

Meikle, Graham: "It's Like Talking to a Wall". In: Wittkower, Dylan E. (ed.): Facebook and Philosophy: What's on your Mind? Chicago: Open Court 2010. 13-20.

Muhr, Sara Louise and Pedersen, Michael: "Faking It on Facebook". In: Wittkower, Dylan E. (ed.): Facebook and Philosophy: What's on your Mind? Chicago/La Salle, Open Court 2010. 265-275.

Vallor, Shannon (2011): Flourishing on Facebook: Virtue Friendship \& New Social Media. Ethics and Information Technology 13 (1).

Žižek, Slavoj: The Plague of Fantasies. London/New York, Verso 1997. 